\title{
Tyrkiets gadekryds
}

Af tidens enorme omvæltninger i den muslimske verden har vi valgt Tyrkiet som tema, ikke mindst fordi det store potentielle EU-land i den seneste tid har oplevet både store fremskridt og tilbageslag. Fremskridt fordi den tidligere politisk passive tyrkiske ungdom blev vækket af Gezi Park bevægelsen, der ventes at sætte varigt præg på Tyrkiet. Tilbageslag fordi regeringsleder Erdogan valgte vold som svar. Men politibrutaliteten førte også godt med sig: dialog mellem sociale lag, religioner og etniske grupper, som ikke tidligere har talt sammen.

Erdogan er stadig uhyre populær, men når det næppe varer ved, har han, som beskrevet i dette nummer, kun sig selv at takke for det. Vi peger også på et andet tilbageslag, at Tyrkiet med stadig flere konflikter med naboer har fraveget den tidligere politik for godt naboskab. Tyrkiet er stadig mere en del af regionens konflikter og stadig mindre en del af løsningen.

En bidragyder til temaet spørger, om Erdogan ser sig selv i billedet af Egyptens afsatte præsident Morsi. Tyrkiet gik først - og længe før det arabiske forår - med at bringe islamister til magten ved stemmeurnerne.

Det var efter fire militærkup, og Erdogan har sikkert god grund til at frygte et nyt, hvis tyrkisk militær - omend det er svækket - får gode ideer fra Egypten.

Ikke mindst udviklingen i Tyrkiet og Egypten har genaktualiseret spørgsmålet, om modernitet og demokrati er foreneligt med islam, som det dynamiske og moderne Tyrkiet hidtil har tydet på. Men hvad er det, som sker, når Egypten griber til militærkup, og Erdogans Tyrkiet tager kraftig afstand?

Kombinationen af folkelige tyrkiske protester og den politiske udvikling i Egypten er en alvorlig udfordring for tyrkisk udenrigspolitisk. Dertil kommer, at udviklingen i Syrien lægger hårdt pres på Ankara om det kurdiske spørgsmål.

I de seneste år har AKP's politik mest taget sigte på at trænge militæret ud af politik. Nu har Tyrkiet ændret sin lov for de væbnede styrker, tilsyneladende for at forhindre en tyrkisk version af Egypten.

Blandt Tyrkiets aktuelle udenrigspolitiske bestræbelser er at styrke relationerne til Iran, der adskiller sig fra andre lande med muslimsk flertal ved at sætte islam over nationale interesser. Vi sætter således også fokus på Iran efter valget af den mest moderate præsidentkandidat, Hassan Rowhani, og den ideologisk dominerede iranske udenrigspolitiks betydning for hele regionen.

\section{Redaktionen}

